\title{
Turner Syndrome and Apparent Absent of Uterus : A Case Report
}

\author{
Munira Ferdausi ${ }^{1}$
}

\begin{abstract}
A 15 years young fair girl presented with primary amenorrhoea. Findings on her physical examination included short stature, cubitus valgus, slightly webbed neck, absent of secondary sexual characters, broad chest with widely spaced nipples and absence of pubic \& axillary hair. Except for the above, her systemic examination was unremarkable. A gynecological examination failed to reveal any abnormality. Ultrasound examination of abdomen revealed absent uterus and ovaries. Serum T3, T4 were within normal level, but TSH level was in slightly raised. Plasma FSH \& LH were high with low estradiol level suggestive of hypergonadotrophic hypogonadism. Karyotyping confirmed the diagnosis of Turner's syndrome $(45, \times 0)$.
\end{abstract}

TAJ 2010; 23(1): 91-94

\section{Introduction}

Turner's syndrome, a disorder of females is characterized by the absence of all or part of a normal second sex chromosome, leading to a constellation of physical findings that often includes congenital lymphendema, short stature and a gonadal dysgenesis. ${ }^{1,2}$

Turner's syndrome occurs in 1 in 2500 to 1 in 3000 live born girls. Approximately half have monosomy $(45, \mathrm{X})$ and 5-10 percent have a duplication (isochromosome) of the long arm of one $X(46, X, 1(X q)$. Most of the rest have mosaicism for 45 , $X$, with one or more additional cell lineages.

Historically, in 1938 Turner's described the syndrome which has become synonymous with his name. Currently the syndrome is referred to by such other designations as ovarian dwarfism, ovarian agenesis, syndrome of rudimentary ovaries and Bonnevie-Ullrich syndrome. We also currently use the term gonadal dysgenesis agree with Grumbach et al. $^{3}$ and his associates introduced the gonadal dysgenesis.
The classic picture of turner's syndrome or gonadal dysgenesis is well known and is associated with a variety of other anomalies. ${ }^{4}$ In a review of the literature,the woman involved are described as having primary amenorrhoea, are of short stature but not dwarfed and possess rudimentary ovaries. The sexual hair is scant or absent and there is conspicuous lack of breast development. The uterus and vagina are infantile in type. There is also an associated high urinary gonadotropin level \& lowered urinary 17 ketosteroids. Many of these females have deep set ears, cubitus valgus, an increased carrying angle between the forearm and upper arm, and various ocular abnormalities. In the severe forms of the syndrome there are various degrees of webbing of the neck, coarctation of the aorta associated with an unexplained hypertension, deformity of the nails \& a high arched palate. ${ }^{5}$

Following turner's report researchers have shown by investigations of the chromosomal sex patterns as determined by blood pressure ${ }^{6}$, skin biopsy ${ }^{7}$ and oral mucosal smears ${ }^{8}$ that the majority of patients with ovarian dysgenesis are chromatine negative.

${ }^{1}$ Assistant Professor, Department of Obs \& Gynae, Rajshahi Medical College, Rajshahi. 


\section{Case history}

A 15 years fair young girl from Mirpur,Kushtia, presented with the complaint of primary amenorrhoea, no breast development, no pubic hair like her younger \& older sisters. Her height was 57 inches and weight 45kg.Her IQ level was well \& good. Her past history is otherwise not remarkable. Detailed menstrual history revealed that she never had a menarche or vaginal spotting. There was no history of cyclical abdominal pain.Patient did not report any history of chemotherapy, radiotherapy, trauma or surgery to gonads. Past medical history was negative for mumps, tuberculosis or any major systemic illness.

Patient was a product of non-consanguineous marriage. She was born to a full term pregnancy with normal vaginal delivery at home. There was no history of obstructed labor, ante-partum or post partum haemorrage, congenital birth defects, birth asphyxia or neonatal jaundice.

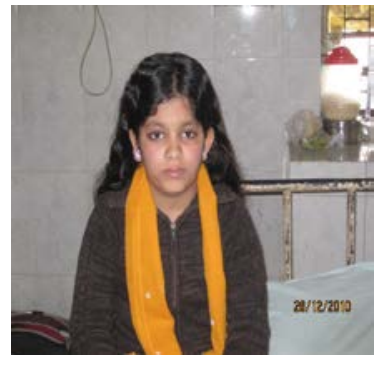

Fig. 1

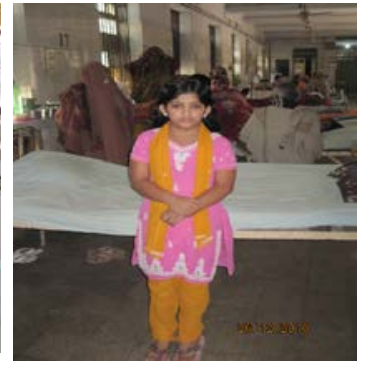

Fig. 2
On close inquiry, it was revealed that she was considerably shorter than her peers. The patient reported that she started lagging behind in her height as she approached $8^{\text {th }}$ or $9^{\text {th }}$ year of life. She also noticed her secondary sexual characters failed to develop properly as she reached her pubertal age. She has normal intelligence.

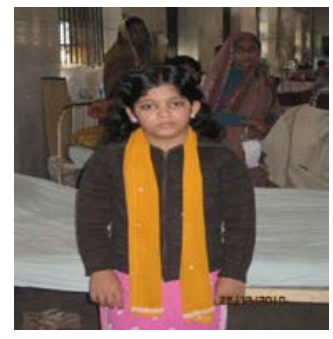

Fig. 3

On examination, the patient was hemodynamically stable. She had a blood pressure of $110 / 80 \mathrm{~mm}$ of
Hg. Her pulse was 75/min \& regular and respiratory rate of $15 / \mathrm{min}$.

Physical examination on hospitalization revealed a well nourished, reserved appearing female whose head was cove red with moderate growth of dark hair. Her height was.... \& weight.....Cubitus valgus was apparent. As reported by the ophthalmologist her eye ground, visual field and intraocular tension were normal. Skin turgor was good and the neck appeared proportionate to her body size. No webbing was apparent. The chest was the broad shield type (Lisser's sign). The nipples were widely spaced and she had absolutely no breast development. There was no axillary, pubic \& labial hair growths.

Pelvic examination under general anaesthasia, the labia appeared undeveloped \& immature. The external urethral meatus was normally placed and the clitoris presented as a small projection measuring $0.5 \mathrm{~mm}$ in length. The vaginal outlet was virginal in type. On per rectal examination no cervix, no uterus, tubes or ovaries could be palpated.

\section{Laboratory investigations}

Routine laboratory studies revealed the blood count, total cholesterol, blood sugar and urine analysis to be within normal limit. There was no abmormality is detected in chest X-ray, ECG and Echocardiogram. Ultrasound of urogenital system showed no abnormalities in kidney and or pelvis but uterus and ovaries were absent. Her TSH was $6.98 \mathrm{mIu} / \mathrm{L}$. Her FSH level is $36.50 \mathrm{IU} / \mathrm{L} \& \mathrm{LH}$ level is $52.15 \mathrm{IU} / \mathrm{L}$. and Estradiol level is $16.21 \mathrm{pg} / \mathrm{ml}$.

Table : 1

\begin{tabular}{|c|c|c|c|}
\hline \multicolumn{2}{|c|}{ Estimated Value } & \multicolumn{2}{|c|}{ Normal Range } \\
\hline TSH & $\begin{array}{c}6.98 \\
\mathrm{mlU} / \mathrm{L}\end{array}$ & & $0.3-5.0 \mathrm{mlU} / \mathrm{L}$ \\
\hline & & $\begin{array}{l}\text { Follicular } \\
\text { Ovulation }\end{array}$ & $\begin{array}{l}2.84-13.74 \mathrm{lU} / \mathrm{L} \\
15.05-72.20 \mathrm{lU} / \mathrm{L}\end{array}$ \\
\hline LH & $52.15 \mathrm{lU} / \mathrm{L}$ & $\begin{array}{l}\text { Luteal } \\
\text { Menopausal } \\
\text { Follicular }\end{array}$ & $\begin{array}{l}1.72-13.26 \mathrm{lU} / \mathrm{L} \\
21.61-57.60 \mathrm{lU} / \mathrm{L} \\
1.82-7.75 \mathrm{lU} / \mathrm{L}\end{array}$ \\
\hline FSH & $36.50 \mathrm{lU} / \mathrm{L}$ & $\begin{array}{l}\text { Ovulation } \\
\text { Luteal } \\
\text { Menopausal } \\
\text { Female }\end{array}$ & $\begin{array}{l}5.17-29.25 \mathrm{lU} / \mathrm{L} \\
0.75-4.15 \mathrm{lU} / \mathrm{L} \\
28.21-82.07 \mathrm{lU} / \mathrm{L} \\
31-417 \mathrm{pg} / \mathrm{ml}\end{array}$ \\
\hline $\begin{array}{l}\text { Estradiol } \\
\text { (E2) }\end{array}$ & $16.21 \mathrm{pg} / \mathrm{ml}$ & $\begin{array}{l}\text { Adult } \\
\text { Post } \\
\text { Menopausal } \\
\text { Pregnancy }\end{array}$ & $\begin{array}{l}5-63 \mathrm{pg} / \mathrm{ml} \\
\text { Upto } 30000 \mathrm{pg} / \mathrm{ml}\end{array}$ \\
\hline
\end{tabular}




\section{Chromosome analysis report}

Karyotype: (Analysis performed by peripheral blood lymphocyte culture with G-banded)

Total no of chromosome: 45

No of autosome: 22

No of sex chromosome: $\mathrm{X}$

Karyotype: 45, X

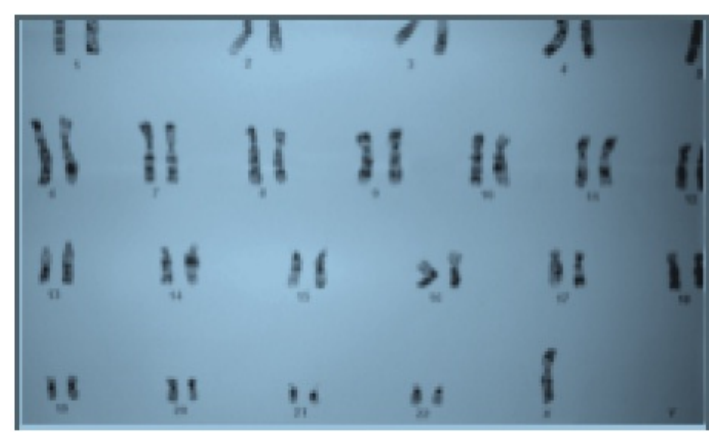

Fig. 4: Karyotyping : 45 XO cell line.

The combination of Turner's syndrome and an absent of uterus was very unusal. The patient \& her family were informed of the unusal findings and she was started an oestrogen replacement therapy with incremental doses of ethinylestradiol. Because of the extremely unusal nature of her clinical findings a repeat ultrasonography scan performed following six months of oestrogen therapy. To our surprise the repeat ultrasonogram scan revealed a infantile uterus measuring about $37 \mathrm{~mm} \times 6 \mathrm{~mm}$. Further imaging after a period of oestrogen replacement is recommended if initial scans fail to identify any uterine tissue.

\section{Discussion}

Turner's syndrome is characterized by streak gonads within phenotypic females without somatic abnormalities. The existence of uterus is important in definition of gonadal dysgenesis. The absence of uterus has been regarded by a number of authors as a criterion for the diagnosis of androgen insensitivity syndrome.

There was absent of uterus in our patient with no secondary sexual characters. There was not a family history of primary amenorrhoea.
In our case gonadotropin levels was over the post menopausal level (FSH 36.50IU/L, LH 52.15 IU/L and estradiol was under the lowest measurable range $(16.21 \mathrm{pg} / \mathrm{ml})$. The lack of menstruation opr breast development was related with insufficiency of gonadotropins.

\section{Comment}

The incidence of primary amenorrhoea is reported to be less than five percent of patient in a general gynecologic practice. ${ }^{9}$. it has also been reported ${ }^{10}$ that 43 percent of cases of primary amenorrhoea are cases of gonadal dysgenesis (turner's syndrome) or of testicular feminization.

After puberty, the diagnosis of gonadal dysgenesis is usally made when a female has primary amenorrhoea in conjunction with the absences of secondary sex characteristics and a variety of congenital defects.

It is generally agreed that women with gonadal dysgenesis should be encouraged to live normal lives and to indulge in normal marital relations. They should, however, se be advised that under the circumstances they will be infertile. The psychologic and physical well being of these patients can be helped greatly by the oral administration of oestrogens because of the ability of these hormones to develop and maintain the secondary sex characteristics. The patient in this case report has been put on this type of therapy with satisfactory results

\section{References}

1. Turner $\mathrm{HH}$. A syndrome of infantilism,congenital webbed necks and cubitus valgus. Endocrinology 1938; 23:566-74

2. Ford $\mathrm{CE}$, Jones $\mathrm{KW}$, Polani PE, de Almeida JC, Biggs $\mathrm{JH}$. A sex chromosome anomaly in a case of gonadal dysgenesis (turner's syndrome). Lanced 1959; 1:711-3

3. Grumbach, M.M, J.J. Van Wyk \& L.Wilkins, chromosomal sex in gonadal dysgenesis (ovarian agenesis) Relationship to male Pseudohermaphrodism \& theories of human sex differentiation. J. Clinical endocrinology \& Metab, 15; 1161, 1955 
4. Richart, $\mathrm{R}$ \& Benirschke, diagnosis of gonadal dysgenesis in newborn infants. J obs \& gyn 15:621, 1966

5. W. F. Bernell James, F.A.C.S., F I.C.S. Ovarian dysgenesis (Turner's syndrome). A case report. J. of the national Medical Assocaiation. Vol 56, no-6, p-511.

6. Del Castillo, E.B.,F.A.A.De La Biaze, and J.Argonz. Syndrome of rudimentary ovaries with estrogenic insufficiency \& increaser in gonadotropins. J. Clin.Endocrinology 7:385, 1947
7. Moore, K.L.,L Barr. Smears from the oral mucosa in the detection of chromosomal Sex. Lancet 2:57, 1955

8. Robert B. greenblatt, O. M, De costa, and Vazqueze. Oral mucosal smears in detection of genetic sex. J, A. M.A.161:683, 1956

9. Novak, E.R.andf G.S.Jones. Novak's Textbook of gynecology, ed-6 Baltimore, The Williams \& Wikins co.1961 pp-668-669

10. Jacobs, P.A., et al. Cytogenetic studies in primary amenorrhoea. Lanced, 1:1183, 1961

All correspondence to: Munira Ferdausi Assistant Professor Department of Obs \& Gynae Rajshahi Medical College. 